\title{
Alveolar surfactant and adult respiratory distress syndrome
}

\section{Pathogenetic role and therapeutic prospects*}

\author{
W. Seeger, A. Günther, H.D. Walmrath, F. Grimminger, and H.G. Lasch \\ Zentrum für Innere Medizin, Justus-Liebig-Universität Gießen
}

Summary. The adult respiratory distress syndrome (ARDS) is characterized by extended inflammatory processes in the lung microvascular, interstitial, and alveolar compartments, resulting in vasomotor disturbances, plasma leakage, cell injury, and complex gas exchange disturbances. Abnormalities in the alveolar surfactant system have long been implicated in the pathogenetic sequelae of this lifethreatening syndrome. This hypothesis is supported by similarities in pulmonary failure between patients with ARDS and preterm babies with infant respiratory distress syndrome, known to be triggered primarily by lack of surfactant material. Mechanisms of surfactant alterations in ARDS include: (a) lack of surface-active compounds (phospholipids, apoproteins) due to reduced generation/ release by diseased pneumocytes or to increased loss of material (this feature includes changes in the relative composition of the surfactant phospholipid and/or apoprotein profiles); (b) inhibition of surfactant function by plasma protein leakage (inhibitory potencies of different plasma proteins have been defined); (c) "incorporation" of surfactant phospholipids and apoproteins into polymerizing fibrin upon hyaline membrane formation; and (d) damage/inhibition of surfactant compounds by inflammatory mediators (proteases, oxidants, nonsurfactant lipids). Alterations in alveolar surfactant function may well contribute to a variety of pathophysiological key events encountered in ARDS. These include decrease in compliance, ventilation-perfusion mismatch including shunt flow due to altered gas flow distribution (atelectasis, partial alveolar collapse, small airway collapse), and lung edema formation. Moreover, more

Abbreviations: $\mathrm{ARDS}=$ adult respiratory distress syndrome; IRDS = infant respiratory distrss syndrome; $P C=$ phosphat idylcholine; $\mathrm{PG}=$ phosphatidylglycerol; $\mathrm{PE}=$ phosphatidyleth anolamine $; \mathrm{PS}=$ phosphatidylserine $; \mathrm{PI}=$ phosphatidylinositol; $\mathrm{Sph}=$ spingomyelin $; \mathrm{BAL}=$ bronchoalveolar lavage $; \mathrm{TNF}=\mathrm{tu}-$ mor necrosis factor

* Dedicated to Prof. Dr. N. Zöllner on the occasion of his 70 th birthday speculative at the present time, surfactant abnormalities may add to a reduction in alveolar host defense competence and an upregulation of inflammatory events under conditions of ARDS. Persistent atelectasis of surfactant-deficient and in particular fibrin-loaded alveoli may represent a key event to trigger fibroblast proliferation and fibrosis in late ARDS ("collapse induration"). Overall, the presently available data on surfactant abnormalities in ARDS lend credit to therapeutic trials with transbronchial surfactant administration. In addition to the classical goals of replacement therapy defined for preterm infants (rapid improvement in lung compliance and gas exchange), this approach will have to consider its impact on host defense competence and inflammatory and proliferative processes when applied in adults with respiratory failure.

Key words: Adult respiratory distress syndrome Alveolar surfactant - Surfactant phospholipids Surfactant apoproteins - Surfactant inhibition Hyaline membranes

The adult respiratory distress syndrome (ARDS) is characterized by different states of acute impairment of pulmonary gas exchange. Underlying noxious events may directly affect lung parenchyma from the alveolar side (e.g., gastric acid aspiration), or - more classically - the lung vasculature may be primary target site of circulating humoral or cellular mediators activated under conditions of sytemic inflammatory events such as sepsis or severe polytrauma $[102,103]$. Key pathophysiological features of the initial "exudative" phase of ARDS include: (a) increase in capillary endothelial and alveolar epithelial permeability, (b) leakage of protein-rich edema fluid into interstitial and alveolar spaces, (c) increase in pulmonary vascular resistance with maldistribution of pulmonary perfusion, (d) alveolar instability with formation of atelectases and ventilatory inhomogeneities, and (e) 
severe disturbances in gas exchange characterized by ventilation-perfusion mismatch and extensive shunt flow. This exudative phase may persist for days to weeks, and full recovery without persistent loss of lung function is well possible during this period of acute respiratory distress. New inflammatory events, such as recurrent sepsis or acquisition of secondary (nosocomial) pneumonia, may repetitively worsen the state of lung function and then progressively trigger proliferative processes with mesenchymal cell activation and rapidly ongoing lung fibrosis. Thus, within a few weeks the lung architecture may become dominated by thickened fibrotic alveolar septae and large interposed airspaces ("honeycombing"). Prognosis is very poor during this phase of ARDS, and only partial recovery of lung function may be achieved in the few survivors from this late phase of disease.

The alveolar space of all mammalian lungs is covered by a complex surfactant system, which is essential to make alveolar ventilation and gas exchange feasible at physiological transpulmonary pressures. It is composed mainly of lipids $(\approx 90 \%)$ and proteins $(\approx 10 \%)[28,41,42,120]$. Apart from a minor amount of neutral lipids $(\approx 10-20 \%)$, phospholipids $(\approx 80-90 \%)$ represent the predominant class of lipids in this surface lining material. Among those, phosphatidylcholine (PC; $\approx 70$ $80 \%$ of phospholipids, $50-60 \%$ substituted with the saturated palmitic acid) and phosphatidylglycerol $(\mathrm{PG} ; \approx 10 \%$ of phospholipids, bearing a large percentage of unsaturated fatty acids) represent the predominant classes; phosphatidylethanolamine (PE), phosphatidylserine (PS), phosphatidylinositol (PI), and sphingomyelin (Sph) are regularly found in low percentages. About half of the protein mass of the alveolar lining layer represents the surfactant-specific apoproteins SP-A (28 kDa), SP-B (8 kDa), SP-C (5 kDa), and SP-D (43 kDa; all molecular weights given for reducing conditions; [ $23,41,46,85,90])$. The predominant, and in some compounds exclusive, source of the different lipid and protein components of the alveolar surfactant system are the alveolar epithelial cells type II [41, 46, 90]. A complex and yet not fully understood interaction between phospholipids and surfactant apoproteins results in far-reaching reduction in the alveolar surface tension, approximating zero $(\mathrm{mN} / \mathrm{m})$ values at end expiration, with limited increase in surface tension upon alveolar surface enlargement during inspiration. Such extremely low surface tension may only be achieved by dense "packing" of some rigid lipid material such as dipalmitoyl-PC in the surface film.

However, characteristics of fluidity are similarly essential for removal of surface film compounds into the bulk phase during surface (over)-compression and rapid reentry and respreading of these compounds upon reexpansion of the surface area. Tubular myelin, a unique morphological structure appearing in the alveolar subphase, appears to be of major functional importance in this context [26, $114,125]$. Studies focusing on the biophysical properties of individual surfactant compounds (for review see $[46,90,120]$ ) have underlined the importance of dipalmitoyl-PC and unsaturated PG and elaborated a key role of the highly hydrophobic low molecular weight apoproteins SP-B and SP-C for adsorption facilities and dynamic surface tension lowering properties $[24,47,83,92,93,108-$ $110,122,123,127,128]$. Although several authors have reported on a cooperative effect of SP-A with the hydrophobic apoproteins on adsorption kinetics $[19,47,71,92,98]$, the predominant function of this protein may be the regulation of the surfactant pool size in the alveolar space. SP-A binds to dipalmitoyl-PC, promotes the uptake of phospholipids into type II cells via receptor-operated events, and inhibits secretion of surfactant compounds by this cell type $[74,95,100]$. In addition, SP-D and SP-A might be involved in host defense mechanisms of the lower airways in vivo, as they function as opsonins for alveolar macrophage phagocytosis of bacteria and viruses in vitro [64-66, 116].

Surfactant deficiency has been established as the primary cause of the respiratory distress syndrome in preterm infants (IRDS), and transbronchial administration of natural surfactant preparations has been proven to be beneficial in this disease [22, 49]. Surfactant abnormalities may also be involved in the sequelae of pathogenetic events in ARDS; however, due to the diversity of underlying triggering mechanisms and the complexity of pathophysiological events in ADRS, any evaluation of the role of surfactant in this disease is much less certain. This review focuses on two questions: (a) What is the present evidence for surfactant abnormalities in patients with ARDS? (b) Which pathophysiological events encountered in the course of ARDS may be attributed to surfactant abnormalities? These aspects aim to provide a rational basis for the more general question of whether transbronchial surfactant administration may become a profitable therapeutic approach in patients with ARDS as it is in IRDS.

\section{Alteration of surfactant in ARDS}

In early postmortem investigations in lungs from patients who had died in ARDS, initial evidence for severe impairment of surfactant function was 
Table 1. Impairment of surface activity in ARDS

\begin{tabular}{|c|c|c|c|c|}
\hline & Material & Method & Variable & Change* \\
\hline $\begin{array}{l}\text { Hallman } \\
\text { et al. [39] }\end{array}$ & $\begin{array}{l}\text { BAL, lipid-protein } \\
\text { complexes }^{\mathrm{a}}\end{array}$ & Wilhelmy Balance & $\tau \min$ & $\uparrow$ \\
\hline $\begin{array}{l}\text { Pison } \\
\text { et al. [87] }\end{array}$ & $\mathrm{BAL}^{\mathrm{b}}$ & Wilhelmy Balance & $\begin{array}{l}\text { Hysteresis } \\
\tau \text { min }\end{array}$ & $\stackrel{\downarrow}{\uparrow}$ \\
\hline $\begin{array}{l}\text { Gregory } \\
\text { et al. [29] }\end{array}$ & BAL, crude surfactant pellet ${ }^{c}$ & Bubble Surfactometer & $\begin{array}{l}\tau \min \\
\tau \max \end{array}$ & $\begin{array}{l}\uparrow \\
\uparrow\end{array}$ \\
\hline
\end{tabular}

$\tau \min$, minimum surface tension; $\tau$ max, maximum surface tension; * Change as compared to normal volunteers

a BAL was centrifuged twice $(140 \mathrm{~g}$, supernatant; $10000 \mathrm{~g}$ pellet) and was subjected to a discontinuous sucrose density gradient $(100000 \mathrm{~g}$ ). Material between 0.2 and $1.3 \mathrm{M}$ sucrose ("lipid-protein complex") was used b BAL was separated from cells by centrifuged at $300 \mathrm{~g}$, no further preparation

c BAL was separated from cells by centrifugation at $450 \mathrm{~g}$, supernatant was centrifuged at $48000 \mathrm{~g}$, and the resulting "crude surfactant pellet" was resuspended in saline and used for bubble measurements

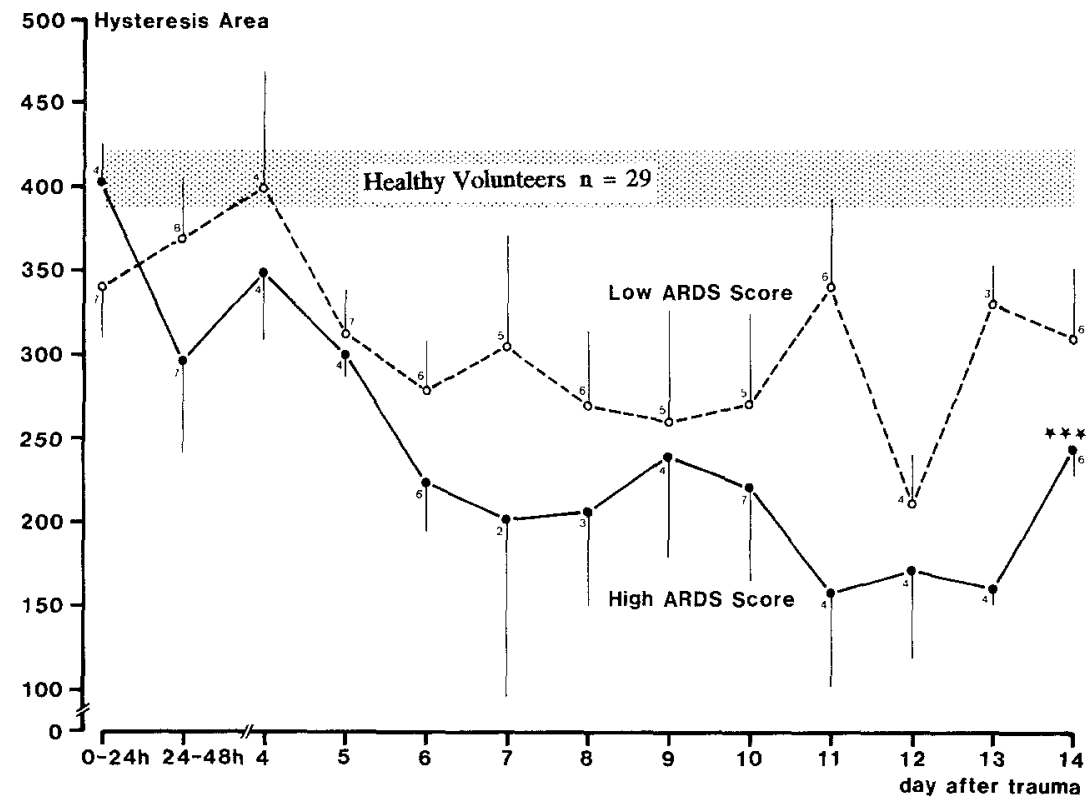

Fig. 1. Time course of surface tension hysteresis area determined in lung lavage material from severely traumatized patients with high and low ARDS scores. Repetitive flexible bronchoscopy for serial determination of alveolar surfactant function was performed within 14 days after trauma; the number of samples for each posttrauma day is indicated. Biophysical measurements were undertaken in diluted surfactant material in the Wilhelmy balance/Langmuir trough system; the hysteresis of the surface tension-surface area realationship is given (arbitrary units). Shaded area, mean $\pm \mathrm{SE}$ for healthy volunteers. The groups with high and low ARDS scores differ significantly $(P<0.001)$. (From [87]) obtained [86]. More direct proof was provided by studies of this group and of other investigators with biophysical analysis of bronchoalveolar lavage fluids (BAL) obtained by flexible bronchoscopy during the active state of the disease [29, 39, 87]. Compared to normal volunteers, BAL samples of these patients showed increased minimal surface tension and decreased hysteresis of the surface tension-surface area relationship, two presumably most critical variables of surfactant function in vivo (Table 1). In addition, the extent of impairment of biophysical surfactant function was correlated with the severity of ARDS (Fig. 1). Recently, elevated minimal surface tension values were also determined for surfactant samples obtained from patients at risk for ARDS [29]. Several factors may underlie such loss of surface activity in ARDS; those discussed below are the following: lack of surface-active compounds (phospholipids, apoproteins), change in phospholipid and apoprotein profiles, inhibition of surfactant function by plasma protein leakage, "incorporation" of surfactant in fibrin/hyaline membranes, and damage to surfactant compounds by inflammatory mediators (proteases, oxidants, nonsurfactant lipids, etc.).

\section{Lack of surface-active compounds and change in phospholipid and apoprotein profiles}

As summarized in Table 2, clinical studies addressing the phospholipid composition of surfactant samples obtained from patients with ARDS have revealed three important features. First, the overall content of phospholipids was found to be de- 
Table 2. Phospholipid content and profile in ARDS

\begin{tabular}{|c|c|c|c|c|c|c|c|c|}
\hline & \multicolumn{2}{|c|}{ Hallmann et al. [39] } & \multicolumn{3}{|c|}{ Pison et al. [87] } & \multicolumn{3}{|c|}{ Gregory et al. [29] } \\
\hline & $\begin{array}{l}\text { Normal } \\
(\mu \mathrm{M})\end{array}$ & $\begin{array}{l}\text { ARDS } \\
(\mu \mathrm{M})\end{array}$ & $\begin{array}{l}\text { Normal } \\
(\mu \mathrm{g} / \mathrm{ml})\end{array}$ & $\begin{array}{l}\text { Low- } \\
\text { score } \\
\text { ARDS } \\
(\mu \mathrm{g} / \mathrm{ml})\end{array}$ & $\begin{array}{l}\text { High } \\
\text { score } \\
\text { ARDS } \\
(\mu \mathrm{g} / \mathrm{ml})\end{array}$ & $\begin{array}{l}\text { Normal } \\
(\mu \mathrm{M} / \mathrm{ml})\end{array}$ & $\begin{array}{l}\text { At risk } \\
(\mu \mathrm{M} / \mathrm{ml})\end{array}$ & ARDS \\
\hline \multirow[t]{2}{*}{$\mathrm{PL}^{\mathrm{a}}$} & 0.6 & 0.6 & 84.1 & 65.7 & 65.1 & 7.99 & 3.48 & 2.47 \\
\hline & $\%^{b}$ & $\%^{b}$ & $\%^{b}$ & $\%^{b}$ & $\%^{b}$ & $\%^{b}$ & $\% b$ & $\%{ }^{b}$ \\
\hline $\mathrm{PC}$ & 73 & 59.5 & 62.8 & 56.3 & 48.1 & 76.27 & 73.32 & 62.64 \\
\hline PG & 12.4 & 0.3 & 10.02 & 1.6 & 1.88 & 11.58 & 7.26 & 6.48 \\
\hline PI & 2.7 & 3.1 & 8.32 & 13.54 & 13.95 & 3.88 & 4.71 & 6.94 \\
\hline $\mathrm{PE}$ & 2.6 & 4.3 & 4.82 & 13.65 & 18.68 & 3.32 & 4.9 & 5.86 \\
\hline Sph & 3.7 & 17.5 & 7.37 & 12.28 & 14.21 & 1.45 & 1.56 & 5.45 \\
\hline
\end{tabular}

a Concentration of phospholipids; BAL and sample preparation as detailed in Table 1

${ }^{b}$ Percentage of total phospholipids

Table 3. Surfactant apoprotein content in ARDS

\begin{tabular}{|c|c|c|c|c|c|}
\hline & \multicolumn{2}{|c|}{ Pison et al. ${ }^{\mathrm{a}}$} & \multicolumn{3}{|c|}{ Gregory et al. ${ }^{b}$} \\
\hline & Normal & ARDS & Normal & At risk & ARDS \\
\hline SP-A $(\mu \mathrm{g} / \mathrm{ml})$ & 2.74 & 1.49 & 123.64 & 49.28 & 29.88 \\
\hline $\mathrm{SP}-\mathrm{B}(\mathrm{ng} / \mathrm{ml})$ & n.m. & n.m. & 1.28 & 0.89 & 0.57 \\
\hline
\end{tabular}

a BAL was separated from cells by centrifugation at $180 \mathrm{~g}$; concentrations given for original lavage fluid; from [89]

${ }^{b}$ Cell-free BAL was concentrated by centrifugation at $48000 \mathrm{~g}$; concentration given for "crude surfactant pellet;" from [29]

creased in two of the three studies performed to date. In addition, this decrease in total phospholipids appeared to be dependent on the severity of ARDS. Second, the relative amounts of the two functionally most important phospholipids, PC and $P G$, were markedly depressed in all three studies. Most strikingly, the PG levels decreased by over $80 \%$ in two of these studies; the decrease in the percentage of $\mathrm{PC}$ was more moderate in all three investigations. Third, all studies demonstrated an increase in the relative amounts of PI, $\mathrm{PE}$, and $\mathrm{Sph}$.

Due to the late detection and - in case of SP-B and SP-C - the extreme hydrophobic nature of the surfactant apoproteins, appropriate analytical techniques for measurement of these essential surfactant compounds have only recently become available; SP-C quantification in BAL samples is still an unresolved problem. Two recent studies measuring SP-A, one also measuring SP-B, in BAL samples from patients with ARDS have demonstrated an impressive decline of these surfactant apoproteins (Table 3). Again, some decrease in these functionally important compounds was also observed in patients at risk for ARDS.

The reported changes in lavage phospholipid and apoprotein contents in patients suffering from ARDS are very much reminiscent of biochemical profiles characterized in neonates with immature lungs and IRDS [120]. They are thus likely to reflect injury of type II pneumocytes with altered lipid and apoprotein metabolism and/or secretion by this cell type. In addition, the increase in PI, $\mathrm{PE}$, and Sph may be due to some surfactant "contamination" with membrane phospholipids from different injured cell types, and there may be leakage of plasma phospholipids under conditions of increased endothelial and epithelial permeability. Finally, as discussed below, incorporation of phospholipids into hyaline membranes may also contribute to the alterations in phospholipid and apoprotein profiles.

\section{Inhibition of surfactant function by plasma protein leakage}

Leakage of plasma proteins into the alveolar space may substantially contribute to surfactant alterations in ARDS. Measurements of the protein content in BAL samples from these patients persistently show markedly increased levels compared to normal controls. Protein leakage is an early event in the sequence of pathogenetic events in ARDS and is related to the severity of the disease (see e.g., [87]; Fig. 2). Experimental studies in vitro and in vivo have demonstrated that admixture of blood, serum, plasma, or alveolar washings obtained during states of plasma leakage may severe- 

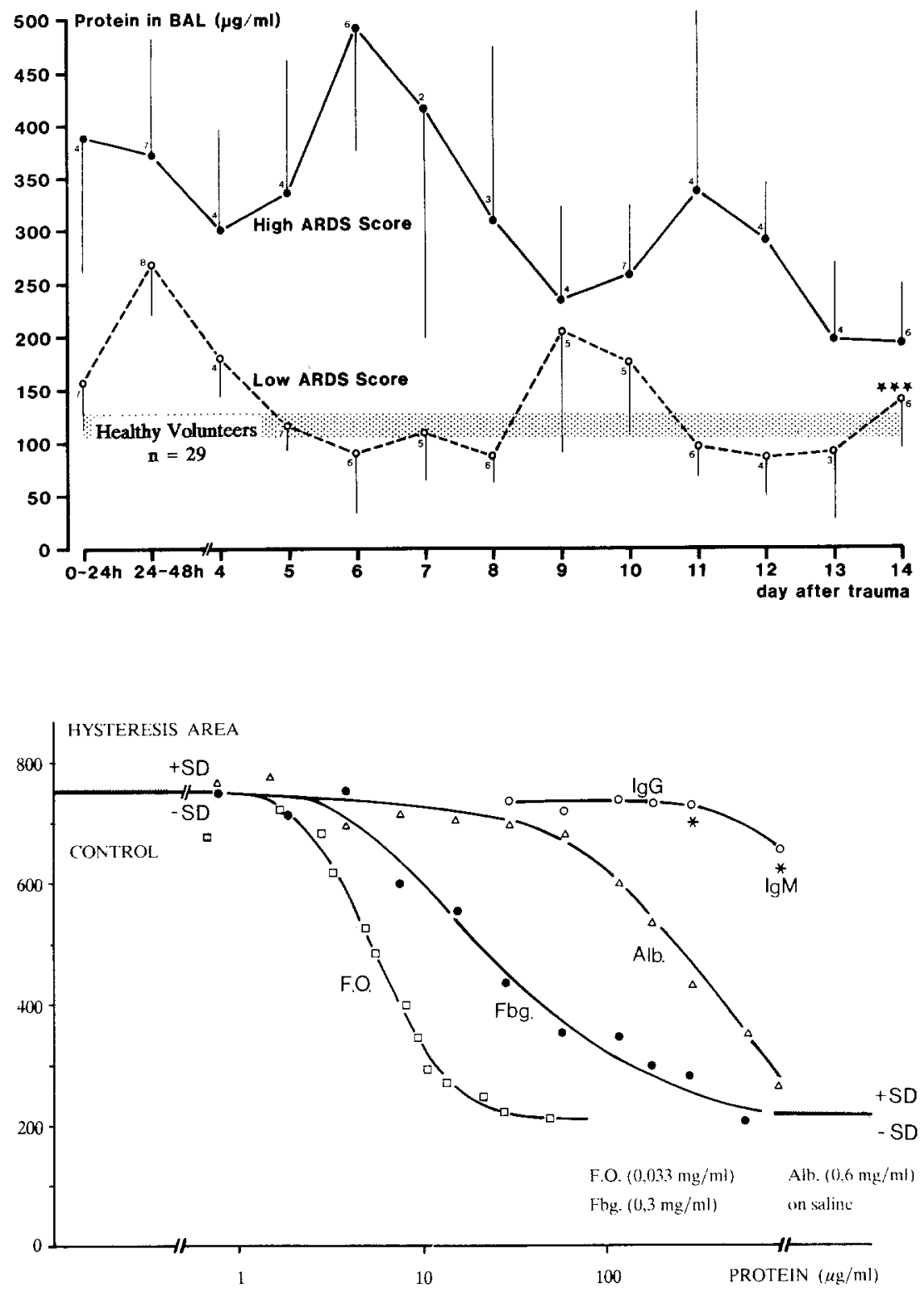

Fig. 2. Time course of BAL protein content in severely traumatized patients with high and low ARDS scores. Repetitive flexible bronchoscopy for serial determination of alveolar surfactant function was performed within 14 days after trauma; the number of samples for each post-trauma day is indicated. Shaded area, mean $\pm \mathrm{SE}$ of BAL protein concentration in healthy volunteers. The groups with high and low ARDS scores differ significantly $(P<0.001)$. (From [87])

Fig. 3. Dose-effect curves of IgG (human), albumin (bovine; $A l b$.), fibrinogen (bovine; $F b g$ ), and fibrin-monomers/-oligomers (bovine; F.O.) on surface tension characteristics of rabbit lung surfactant. Biophysical measurements were undertaken in diluted surfactant material in the Wilhelmy balance/Langmuir trough system (50 $\mu \mathrm{g} / \mathrm{ml}$ phospholipids); the hysteresis of the surface tension-surface area relationship is given (arbitrary units). Shaded area, mean $\pm \mathrm{SD}$ of hysteresis area of control surfactant without protein addition and of protein effects on pure saline. Fibrinmonomers were first dissolved in a small volume in urea TRIS buffer and then bolus-admixed to the surfactant material; arising large fibrin strands (but not small fibrin oligomers) were removed from the soluble phase by centrifugation before measuring surface tension. [106]) ly compromise biophysical surfactant function [7, $9,27,62,73,106,117]$. Among different proteins involved, albumin [19, 27, 51, 105], hemoglobin [50], and in particular fibrinogen or fibrinmonomer $[19,27,52,84,99,105,108,109,115]$ possess strong surfactant-inhibitory properties (see Fig. 3). Concerning fibrinogen, it has been demonstrated that its potency to inhibit surfactant function depends on the surfactant apoprotein profile. Surfactant preparations lacking the hydrophobic apoproteins are extremely sensitive to fibrinogen inhibition, and least sensitivity is noted in the presence of both SP-C and SP-B in near physiological quantities [109, 121]. In addition, a further reduction in surfactant sensitivity to fibrinogen is achieved by supplementation of phospholipid- and hydrophobic apoprotein-based surfactants with SP-A [19].

\section{"Incorporation" of surfactant in fibrin/hyaline membranes}

Intra-alveolar accumulation of clot material, characterized as hyaline membranes, is commonly found in ARDS and other acute or chronic inflammatory diseases of the lung [6, 12, 40,67, 91, 112]. In the alveolar milieu, the extrinsic coagulation pathway represents the predominant clotting sequence. Alveolar macrophages express and shed a procoagulant activity, which is attributable main- 


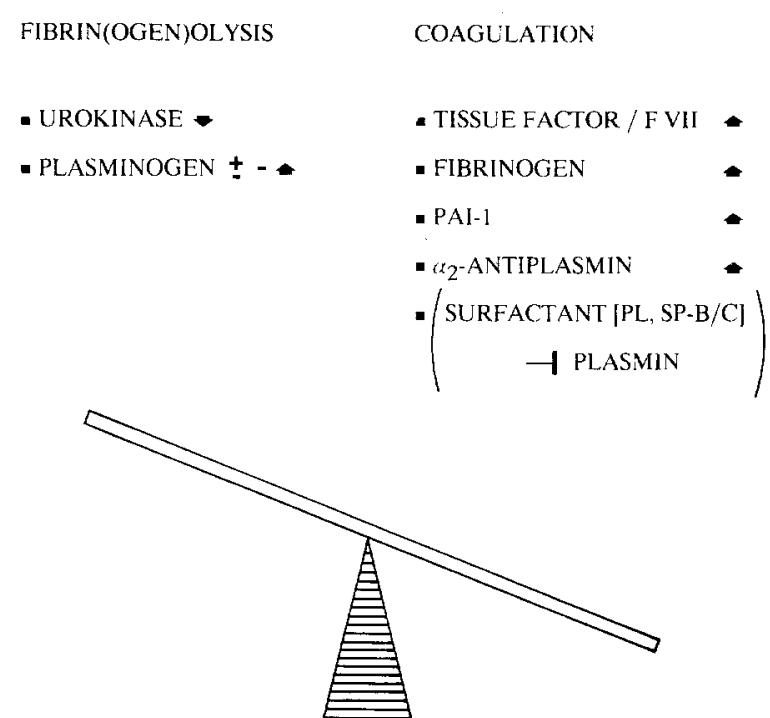

Fig. 4. Hemostatic balance under conditions of ARDS: increase in procoagulant and decrease in fibrinolytic activity in the alveolar space. For details see text. It is hitherto not known whether the plasmin inhibitory capacities of surfactant phospholipids and hydrophobic apoproteins are altered in ARDS

ly to tissue factor in compound with factor VII $[13,14,36,43,59,79,80]$. This alveolar procoagulant activity was found to be markedly increased in ARDS patients (possibly because of local macrophage activation $[55,59,61,107])$ and in several experimental models of acute lung injury [56-58, 60] (Fig. 4). In contrast, concentrations of urokinase-type plasminogen activator, representing the predominant fibrinolysis pathway within the alveolar spaces $[10,15,43,59]$, were noted to be decreased in lavage fluids from patients with ARDS; concomitantly, increased levels of plasminogen activator inhibitor-1 and $\alpha 2$-antiplasmin were detected $[10,59,61,80]$. Moreover, surfactant phospholipid mixtures were found to inhibit plasmin-induced fibrinogenolysis, in particular when combined with the surfactant apoproteins SP-B and SP-C [130]. Thus, the hemostatic balance within the alveolar milieu appears to be shifted toward predominance of procoagulant and antifibrinolytic activity in acutely or chronically inflamed lung regions, in particular in ARDS. Recent investigations performed by this group [131] have demonstrated loss of surfactant phospholipids from the soluble phase due to binding to/within fibrin strands when the process of fibrin polymerization occurred in the presence of surfactant material. In parallel, virtually complete loss of surface activity was noted, with fibrin dose-effect curves ranging two orders of magnitude below the corresponding efficacy range of soluble fibrinogen. ${ }^{31} \mathrm{P}$ nuclear magnetic resonance spectrum analysis has suggested membranelike, highly ordered arrangement of the fibrin-associated phospholipids. Overall, these findings obviously suggest "incorporation" of phospholipids (and possibly hydrophobic apoproteins) into nascent fibrin strands. This phenomenon may cause severe loss of functionally important surfactant compounds in areas with alveolar fibrin and hyaline membrane formation.

\section{Damage to surfactant compounds by inflammatory mediators}

A variety of inflammatory processes are thought to underlie microcirculatory disturbances in ARDS, and mediator generation has also been demonstrated for the alveolar compartment. Free elastase and collagenase activities were repeatedly detected in BAL fluids of patients with ARDS [16, 76]. Oxidative inhibition of the alveolar $\alpha_{1}$-proteinase inhibitor indicated oxygen radical generation in this compartment [17], and increased levels of lysophospholipids (predominantly lyso-PC) [39] suggested increased phospholipolytic activity in the alveolar space under conditions of ARDS. A variety of in vitro studies have addressed putative direct inhibitory effects of inflammatory mediators on biophysical surfactant functions. Inhibitory potencies have been demonstrated for phospholi-

Table 4. Impact of inflammatory mediators on surfactant function: in vitro studies

\begin{tabular}{ll}
\hline Mediator & Effects \\
\hline Phospholipases $\left(\mathrm{A}_{2}, \mathrm{C}\right)$ & - Generation of lysophospholipids \\
& (especially lysoPC) [53] \\
- & Loss of surface activity [53] \\
- & Higher sensitivity toward \\
& inhibition by plasma proteins [18] \\
- & Generation of free fatty acids \\
& (including arachidonic acid) [38] \\
- & Pretranslational inhibitory \\
& effect on the expression of \\
& SP-A and SP-B [126] \\
- & Degradation of SP-A, indirect \\
& evidence for degradation of SP-B \\
Cytokines (TNF) & and SP-C; loss of surface activity \\
& [88] \\
Proteases (elastase) & Decrease in surface activity \\
& {$[101,104]$} \\
Oxygen radicals & Induction of lipid peroxidation \\
& {$[104]$} \\
Lipidmediators & Decrease in surface activity [104] \\
(arachidonic acid) & - Decrease in surface activity [101] \\
PMN & - Degradation of SP-A [101] \\
&
\end{tabular}


pases, proteases, oxygen radicals, free fatty acids, and activated granulocytes (via release of oxygen radicals), as summarized in Table 4. Presently, however, no data are available to quantify the contribution of such surfactant-inhibitory effects of inflammatory mediators to the impairment of surfactant function in patients with ARDS.

\section{Pathophysiological consequences of surfactant alterations in ARDS}

As outlined above, there is strong evidence for severe impairment of the alveolar surfactant system under conditions of ARDS, and several mechanisms may underlie this finding. Thus the question arises of whether and to what extent such surfactant alterations contribute to the sequence of pathogenetic events and the loss of lung functional integrity encountered in this disease. The main issues to be addressed in this context are the following: alteration of lung mechanics; impairment of gas exchange (ventilation/perfusion mismatch due to altered gas flow distribution, shunt flow): lung edema formation (hydrostatic gradient, barrier characteristics); reduction in host defense competence (nosocomial pneumonia); up-regulation of inflammatory events; and "collapse induration", fibroblast proliferation and fibrosis.

\section{Alteration of lung mechanics}

Loss of alveolar surface activity increases surface tension and thereby causes alveolar instability and formation of atelectases. These features must be expected to result in a marked decrease in lung compliance. This basic finding was indeed described even in the very early reports on altered mechanics of postmortem analyzed lungs from patients dying from ARDS [86]. In addition, in a variety of experimental approaches using animal models of ARDS, induction of acute lung injury resulted in significant decrease of compliance [9, $75,77,78,113,119,129]$. Accordingly, transbronchial administration of surfactant was shown to completely or partially restore physiological lung compliance in some of these models $[9,75,77$, $78,113,129]$. In patients with severe ARDS, however, reliable measurements of lung compliance are still difficult to perform, mostly because of uncertainties concerning lung volumes (at which part of the pressure-volume curve does the lung actually range?) and transpulmonary pressures. Moreover, there is presently no reliable in vivo technique to differentiate the contribution of increased alveolar surface tension from that of interstitial congestion and on-going fibrosis to the reduction in lung compliance of ARDS patients. It is well conceivable that surfactant alterations predominate in the early phase of ARDS, whereas fibrotic events gain increasing importance in later states of the disease. Future studies of transbronchial surfactant administration in ARDS patients using appropriate techniques to measure lung mechanics may help to determine the contribution of the alveolar surfactant system to altered lung mechanics in these patients.

Impairment of gas exchange: ventilation/perfusion mismatch and shunt flow

Lack of surface active material has been established as primary cause of severe gas exchange disturbances in IRDS, and dramatic improvement in arterial oxygenation is achieved by transbronchial surfactant application under these conditions [22, 49]. Similarly, experimental approaches in adult animals with removal of alveolar surfactant (lung lavage models [97]) and subsequent transbronchial readministration of surface active material have also underscored the fundamental significance of the alveolar surfactant system for ventilation-perfusion matching in adult lungs $[8,37,97]$. In more realistic models of ARDS, starting with induction of microvascular or alveolar injury, matters are more complex. Shunt flow (perfusion of atelectatic regions) and blood flow through lung areas with low ventilation-perfusion ratios (partial closure of alveolar units or small airways) may well be related to acute impairment of the alveolar surfactant system in such experiments, and transbronchial surfactant administration was found to improve gas exchange conditions in models with protein-rich edema formation due to cervical vagotomy [9], acid aspiration $[72,75,113]$, induction of pneumonia [118], hyperoxic lung injury [54], and administration of $N$-nitroso- $N$-methylurethane $[77,78]$ or oleic acid [129]. The efficacy of surfactant replacement in these models with induction of lung inflammation is, however, lower than in models with primary surfactant depletion (lavage, preterm newborns), which is most probably attributable to inhibitory capacities of leaked plasma proteins and inflammatory mediators, as discussed above. Larger amounts of surfactant material are apparently needed under these conditions in order to surpass, at least partially, such inhibitory capacities. The same feature is probably true for patients suffering from ARDS. Presently, only few case reports on transbronchial (via bronchoscope) "rescue" administration of natural surfactant preparations in patients with severe ARDS are 


\section{PRE SURFACTANT}

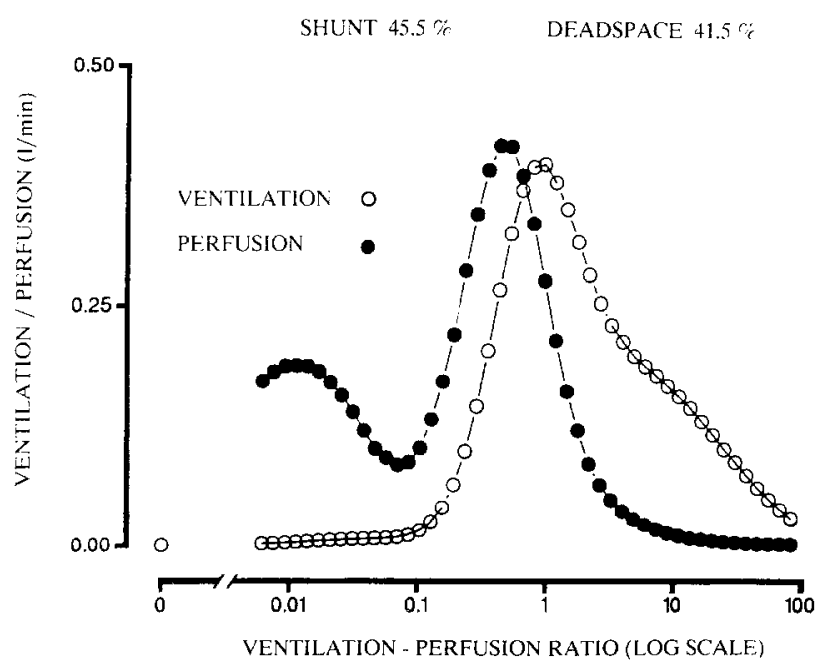

$\underline{3 \mathrm{~h} \text { POST SURFACTANT }}$

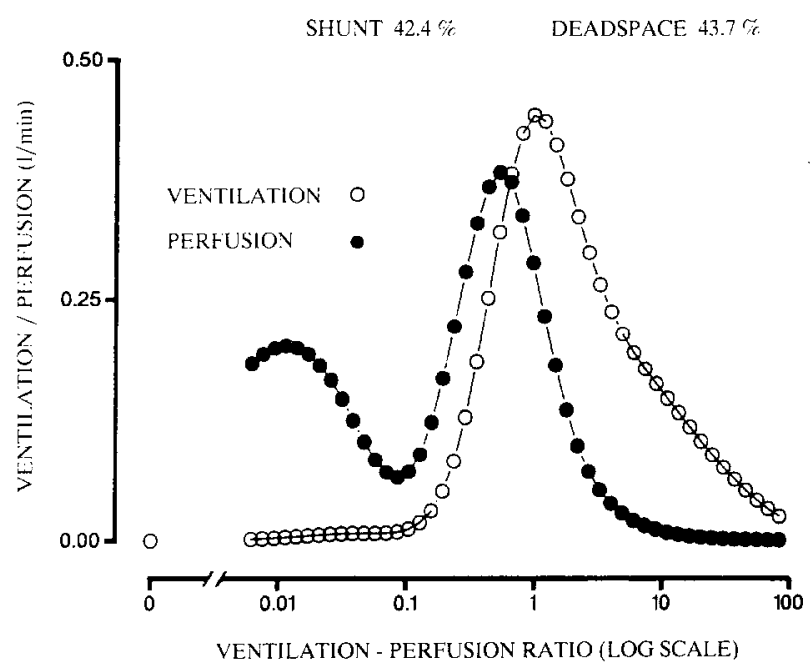

$24 \mathrm{~h}$ POST SURFACTANT

SHLNT $36.5 \%$ DEADSPACE $49.1 \%$

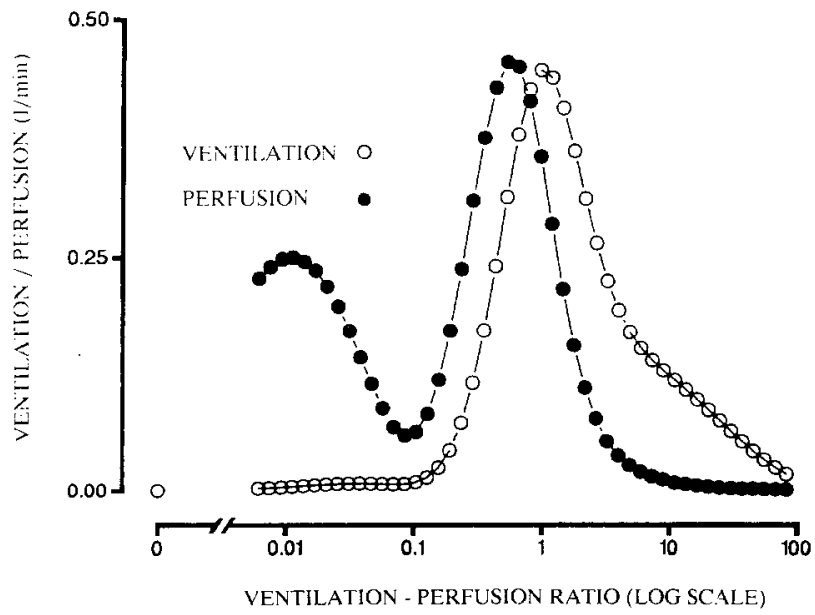

available $[69,96]$; one example from this group is given in Fig. 5. Some more or less impressive improvement of gas exchange conditions was noted in these trials, suggesting that the use of larger amounts of surfactant material would be more promising. Studies with long-term surfactant administration by use of aerosol techniques have been commenced in ARDS patients, but definite data are yet not available. Further diagnostic and therapeutic approaches will be necessary to elucidate the contribution of impaired surfactant function to the gas exchange abnormalities in ARDS, to define whether this contribution is critically dependent on the phase of the disease (large impact in early ARDS, small impact in late ARDS with fibrosis?), and thereby to provide a rational basis for surfactant replacement trials aimed at acutely improving gas exchange conditions in ARDS patients.

\section{Lung edema formation}

Interstitial and alveolar edema is a key finding in ARDS, attributed primarily to increased endothelial and epithelial permeability in the diseased lungs. Surfactant alterations may well contribute, however, to the disturbances in fluid balance in ARDS. Any increase in alveolar surface tension must be expected to result in a decrease in interstitial and thus perivascular pressures and, according to Starling's law, increase transendothelial fluid fluxes into septal and interstitial spaces. Similarly, increased alveolar surface tension favors transepithelial fluid movement into the alveolar spaces. Several experimental studies have indeed demonstrated extensive lung edema formation due to inhibition of surfactant function in vivo by transbronchial detergent administration [11, 81], intra-

Fig. 5. Gas exchange abnormalities in a patient with severe ARDS: impact of transbronchial surfactant administration. The therapeutic intervention was undertaken in a 38 -year-old patient, who developed severe ARDS after extensive gastric acid aspiration, complicated by nosocomial pneumonia. At the time of intervention, he was ventilated for 30 days, and gas exchange was severely compromised in spite of optimizing ventilator settings $\left(\mathrm{FiO}_{2} \approx 0.9\right.$ for 1 week). A multiple inert gas analysis of the ventilation/perfusion distribution demonstrated a large percentage of blood flow shifted to areas of a low ratio, accompanied by extremely high shunt flow (45.5\%). Rescue administration of a natural surfactant preparation (Curosurf; $50 \mathrm{mg} / \mathrm{kg}$ body weight via bronchoscope) was performed; larger amounts of surfactant were not available. Pulmonary shunt flow declined to $36.5 \%$ within $24 \mathrm{~h}$, and blood gases improved concomitantly. Further gradual decline in ARDS severity occurred, and the patient was weaned from the ventilator 12 days after surfactant administration 
Table 5. Host defense properties of the hydrophilic surfactant apoproteins

\begin{tabular}{lll}
\hline & SP-A & SP-D \\
\hline Binding to phospholipids & DPPC & PI \\
Carbohydrate binding region & + & + \\
Binding to alveolar type II cells & $+^{\mathrm{a}}$ & $?$ \\
Binding to alveolar macrophages & $+^{\mathbf{a}}$ & + \\
Receptor-mediated binding to peritoneal macrophages, & - & $?$ \\
PMN, monocytes & & \\
Alveolar macrophages: & $\uparrow$ & $?$ \\
$\quad$ Chemiluminescense & $\uparrow$ & $?$ \\
$\quad \begin{array}{l}\text { Chemotaxis } \\
\text { Herpes simplex phagocytosis }\end{array}$ & $\uparrow(\approx \times 10)$ & $?$ \\
Aggregation of micro-organisms & $\uparrow(\approx \times 15)$ & + \\
Binding to micro-organism & $?$ & gram-negative bacteria, fungi, Pneumocystis \\
Mediation of binding of gram-negative bacteria to & HSV & + \\
alveolar macrophages & $?$ & \\
\hline
\end{tabular}

DPPC, Dipalmitoylphosphatidylcholine; HSV, herpes simplex virus; PI, phosphatidylinositol

a Receptor-mediated

tracheal injection of bile acid [70], cooling and ventilating at low functional residual capacity [1], or plasma lavage [82]. Moreover, the permeability characteristics of the epithelial membrane may be influenced by surfactant deficiencies. Increased transepithelial passage of ${ }^{99 \mathrm{~m}} \mathrm{Tc}-\mathrm{DPTA}$ (from alveolar to intravascular space) and labeled albumin (from intravascular to alveolar space) was observed under experimental conditions of surfactant impairment, and the increased fluxes were reduced by transbronchial surfactant replacement $[25,63$, 70]. Similarly, increased epithelial permeability for ${ }^{99} \mathrm{~m}$ Tc-DPTA is noted in neonates with IRDS [68]. Concerning patients with ARDS, there is presently no conclusive study to evaluate the impact of surfactant abnormalities on lung fluid balance and alveolar epithelial permeability characteristics.

\section{Reduction in host defense competence?}

Nosocomial pneumonia is a feared and frequent complication in ARDS. Envolvement of the alveolar surfactant system in lung host defense mechanisms has long been suggested. Direct cytolysis of several cocci upon in vitro incubation with lung lavage material was described in early reports and attributed primarily to free fatty acids in the surfactant material $[20,21]$. Synthetic phospholipid mixtures and natural surfactant preparations (presumably lacking the hydrophilic apoproteins) were noted to suppress alveolar macrophage priming [48] and phagocytosis as well as tumor necrosis factor (TNF) secretion [111]; this finding is possibly related to the down-regulation of inflammatory events in the alveolar compartment under physiological conditions [94]. The PG fraction of the surfactant phospholipids was found to be particularly effective in this context [3-5]. Finally, the hydrophilic surfactant apoproteins SP-A and SP-D were recently noted to possess distinct immunological properties and may contribute substantially to the host defense mechanisms within the alveolar space (Table 5) [64-66, 116]. They apparently serve as opsonizing agents in this compartment and enhance bacterial and viral phagocytosis and killing. Overall, these aspects are at best mosaics of a complex alveolar host defense system, which largely remains to be defined [94]. Studies directly addressing changes in host defense mechanisms due to surfactant alterations in ARDS patients are still lacking. The marked decrease in SP-A levels in these lungs (see above) may suggest loss of opsonizing capacity and increased susceptibility to nosocomial infections.

\section{Up-regulation of inflammatory events?}

One typical feature of ARDS is the perpetuation of inflammatory events in the microvascular and alveolar compartments, which may continue even after cessation of the primary noxious event (e.g., sepsis, shock, aspiration). Similarly, as discussed for the host defense mechanisms, our knowledge of the regulation of inflammatory processes in the alveolar compartment is only fragmentary. Alveolar cells such as macrophages, type II pneumocytes, and invading granulocytes are rich sources of lipid mediators and cytokines when appropriate- 


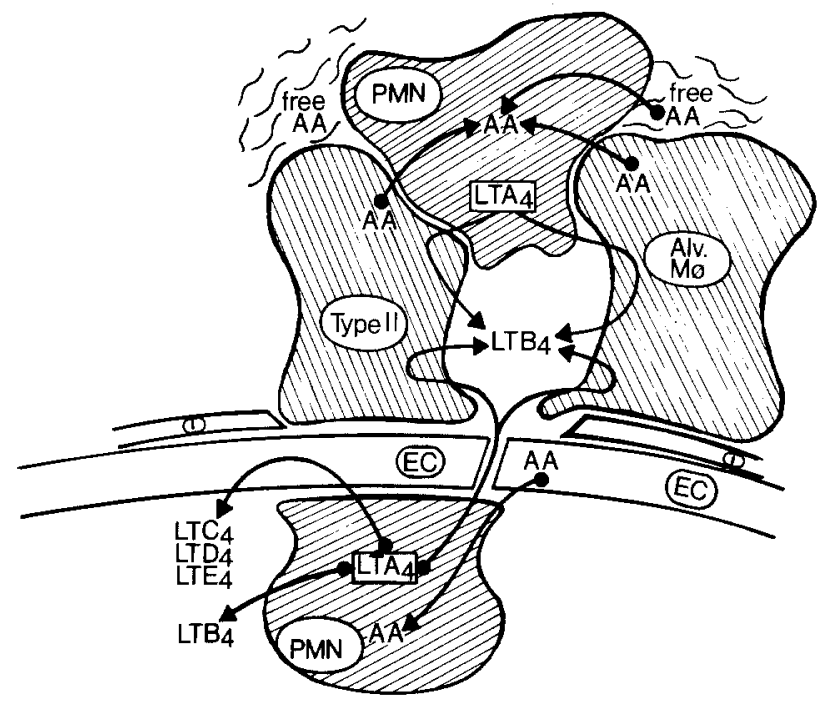

Fig. 6. Intercellular cooperation between granulocytes $(P M N)$ and pulmonary cells in leukotriene $(L T)$ synthesis. Activation of adherent and extravaded PMN by different stimuli results in intercellular shift of the unstable leukotriene precursor $\mathrm{LTA}_{4}$ to different acceptor cells, such as endothelial cells, alveolar macrophages, and type II pneumocytes. Depending on the enzymatic equipment of these acceptor cells, $\mathrm{LTA}_{4}$ is metabolized to cysteinyl-LTs $\left(\mathrm{LTC}_{4}, \mathrm{D}_{4}, \mathrm{E}_{4}\right)$ or $\mathrm{LTB}_{4}$. As a countermove, PMN are "fed" with free arachidonic acid $(A A)$ from these $\mathrm{LTA}_{4}$ acceptor cells, resulting in overall amplification of leukotriene generation. Interestingly, free extracellular AA (contained, for example, in the alveolar surfactant) can substitute for cell-cell shifted AA to perpetuate leukotriene generation in this microenvironment. (Including results from [30-35])

ly stimulated, and intercellular cooperation in inflammatory mediator generation appears to be of major importance; an example for pulmonary capillary and alveolar leukotriene generation is depicted in Fig. 6. Interestingly, the "level" of leukotriene generation in this system of cell-cell cooperation may be largely up-regulated in the presence of free arachidonic acid (leukotriene precursor fatty acid) in the extracellular space, i.e., the alveolar surfactant system. Such increase in lung tissue and surfactant free arachidonic acid content was indeed observed under conditions of experimental [124] and clinical ARDS [39] and may thus contribute to the perpetuation of inflammatory events. As another example of surfactant envolvement in inflammatory processes, Allen et al. [2] recently reported on suppression of interleukin-1 and TNF release from human alveolar macrophages by natural surfactant material, without defining the contribution of single surfactant components to this finding. It is thus easily conceivable that alterations in surfactant composition may have multiple effects on inflammatory processes in the alveolar compartment.

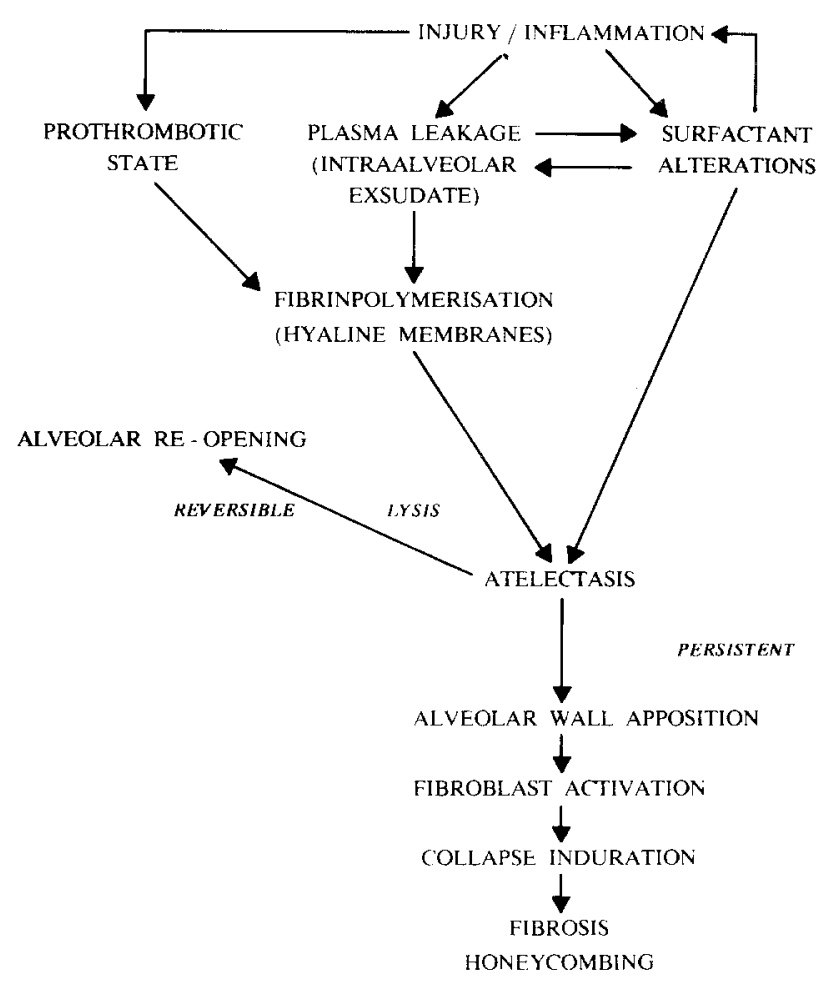

Fig. 7. Possible involvement of surfactant inhibition and alveolar fibrin deposition in the pathogenesis of fibrosis and honeycombing in protracted ARDS. For details see text

\section{"Collapse induration," fibroblast proliferation, and fibrosis}

The proliferative phase of ARDS is characterized by progressive mesenchymal cell activation and proliferation, predominantly in atelectatic regions, and may result in widespread lung fibrosis and honeycombing within a few weeks. Underlying mechanisms may well include a major role of the alveolar surfactant system and of alveolar fibrin deposition, as depicted schematically in Fig. 7. A corresponding sequence of events was suggested for the pathogenesis of lung fibrosis in general by Burkhardt [12] and termed "collapse induration." Basically, this concept starts with persistent atelectasis at sites of extensive loss of alveolar surfactant function, in particular regions with fibrin deposition. Alveolar wall apposition and the fibrin matrix represent a nidus for fibroblast activation, and the concerned alveolar space is definitely lost by deposition of fibrous tissue (collapse induration). Thus, thick indurated septae (or conglomerates of several septae) may exist adjacent to widened (remaining) alveoli to provide the typical morphological image of fibrosis and honeycombing $[6,44,45]$. This concept does not deny an important role of inflammatory mediators, such as TNF, and growth factors 
for the induction of mesenchymal cell activation in late ARDS. However, it provides an explanation for the predominance of fibrosis at sites of persistent atelectasis and fibrin deposition.

\section{Conclusion - Perspective}

Overall, there is good evidence for the assumption that significant surfactant abnormalities occur under conditions of ARDS, and a variety of mechanisms may contribute to this feature. It is thus conceivable that "classical" consequences of surfactant deficiency such as atelectasis formation and loss of compliance, ventilation-perfusion mismatch and shunt-flow, as well as lung edema formation may be related to such surfactant abnormalities in patients suffering from ARDS. However, the extent to which surfactant-related disturbances contribute to the overall pathophysiological events in ARDS cannot presently be quantified and may depend critically on the phase of the disease. Moreover, surfactant abnormalities may have considerable impact on host defense mechanisms, inflammatory events, and fibrosis generation, but no definite evaluation of these aspects can currently be undertaken due to the scarcity of clinical data in these fields. There is, however, no doubt that all these aspects must be addressed when planning transbronchial surfactant administration as a new therapeutic approach in ARDS. Final "design" of a surfactant to be administered under these conditions will have to use proper administration techniques (preferably some kind of aerosolization), aim at acut improvement in lung mechanics and gas exchange, and critically consider its impact on inflammation, host defense, and mesenchymal proliferation in the alveolar compartment.

\section{References}

1. Albert RK, Lakshminarayan S, Hildebrandt J, Kirk W (1979) Increased surface tension favours pulmonary edema formation in anaesthetized dogs' lungs. J Clin Invest 63:1015-1018

2. Allen JN, Herzyk DJ, Wewers MD (1992) Surfactant suppresses interleukin $-1 \beta$ and tumor necrosis factor- $\alpha$ release by human alveolar macrophages. Am Rev Respir Dis 145: A 875

3. Ansfield MJ, Benson BJ (1980) Identification of the immunosuppressive components of canine pulmonary surface active material. J Immunol 125:1093-1098

4. Ansfield MJ, Kaltreider HB, Benson BJ, Caldwell JL (1980) Immunosuppressive activity of canine pulmonary surface active material. J Immunol 122:1062-1066

5. Ansfield MJ, Kaltreider HB, Benson NJ, Shalaby MR (1980) Canine surface active material and pulmonary lymphocyte function studies with mixed-lymphocyte culture. Exp Lung Res 1:3-11
6. Bachofen M, Weibel EF (1982) Structural alterations of lung parenchyma in the adult respiratory distress syndrome. Clin Chest Med 3:35-56

7. Balis JU, Shelley SA, McCue MJ, Rappaport ES (1971) Mechanisms of damage to the lung surfactant system. U1trastructure and quantitation of normal and in vitro inactivated lung surfactant. Exp Mol Pathol 14:243-262

8. Berggren P, Lachmann B, Curstedt T, Grossmann G, Robertson B (1986) Gas exchange and lung morphology after surfactant replacement in experimental adult respiratory distress syndrome induced by repeated lung lavage. Acta Anaesthesiol Scand 30:321-328

9. Berry D, Ikegami M, Jobe A (1986) Respiratory distress and surfactant inhibition following vagotomy in rabbits. J Appl Physiol $61: 1741-1748$

10. Bertozzi P, Astedt B, Zenzius L, Lynch K, LeMaire F, Zapol W, Chapman H (1990) Depressed bronchoalveolar urokinase activity in patients with adult respiratory distress syndrome. N Engl J Med 322:890-897

11. Bredenberg CE, Paskanik AM, Nieman GF (1983) High surface tension pulmonary edema. J Surg Res 34:515-523

12. Burkhardt A (1989) Alveolitis and collapse in the pathogenesis of pulmonary fibrosis. Am Rev Respir Dis $140: 513-524$

13. Chapman HA, Allen CL, Stone L (1986) Abnormalities in pathways of alveolar fibrin turnover among patients with interstitiell lung disease. Am Rev Respir Dis 133:437443

14. Chapman HA, Reilly JJ, Kobzik L (1988) Role of plasminogen activator in degradation of extracellular matrix protein by live human alveolar macrophages. Am Rev Respir Dis 137:412-419

15. Chapman HA, Bertozzi P, Sailor LZ, Nusrat AR (1990) Alveolar macrophage urokinase receptors localize enzyme activity to the cell surface. Am J Physiol 259: L 432-L 438

16. Christner P, Fein A, Goldberg S, Lippmann M, Abrams $W$, Weinbaum $G$ (1985) Collagenase in the lower respiratory tract of patients with adult respiratory distress syndrome. Am Rev Respir Dis 131:690-695

17. Cochrane CG, Spragg R, Revak SD (1983) Pathogenesis of the adult respiratory distress syndrome. $\mathrm{J}$ Clin Invest $71: 754-761$

18. Cockshutt AM, Possmayer F (1991) Lysophosphatidylcholine sensitizes lipid extracts of pulmonary surfactant to inhibition by serum proteins. Biochim Biophys Acta 1086:63-71

19. Cockshutt AM, Weitz J, Possmayer F (1990) Pulmonary surfactant-associated protein A enhances the surface activity of lipid extract surfactant and reverses inhibition by blood proteins in vitro. Biochemistry 29:8424-8429

20. Coonrod JD, Yoneda K (1981) Detection and partial characterization of antibacterial factor(s) in alveolar lining material of rats. J Clin Invest 71:129-141

21. Coonrod JD, Lester RL, Chi Hsu L (1984) Characterization of the extracellular bactericidal factors of rat alveolar lining material. J Clin Invest 74:1269-1279

22. Collaborative European Multicenter Study Group (1988) Surfactant replacement therapy for severe neonatal respiratory distress syndrome: an international randomized clinical trial. Pediatrics 82:683-691

23. Crouch E, Rust K, Marienchek W, Parghi D, Chang D, Persson A (1991) Developmental expression of pulmonary surfactant protein D (SP-D). Am J Respir Cell Mol Biol $5: 13-18$

24. Egan EA, Notter RN, Kwong MS, Shapiro DL (1983) Natural and artificial lung surfactant replacement therapy in premature lambs. J Appl Physiol 55:875-883 
25. Evander E, Wollmer P, Jonson B, Lachmann B (1987) Pulmonary clearance of inhaled ${ }^{99 \mathrm{~m} T c-D T P A}$ : effects of surfactant depletion by lung lavage. J Appl Physiol 62:1611-1614

26. Froh D, Ballard PL, Williams MC, Gonzales J, Goerke J, Odom MW, Gonzales LW (1990) Lamellar bodies of cultured human fetal lung: content of surfactant protein A (SP-A), surface film formation and structural transformation in vitro. Biochim Biophys Acta 1052:78-89

27. Fuchimukai T, Fuchiwara T, Takahashi A, Enhorning G (1987) Artificial pulmonary surfactant inhibited by proteins. J Appl Physiol 62:429-437

28. Goerke J, Clements JA (1986) Alveolar surface tension and lung surfactant. In: Macklem PT, Mead J (eds) Handbook of physiology, American Physiological Society, Bethesda, pp 247-261

29. Gregory TJ, Longmore WJ, Moxley MA, Whitsett JA, Reed CR, Fowler AA, Hudson LD, Maunder RJ, Crim C, Hyers TM (1991) Surfactant chemical composition and biophysical activity in acute respiratory distress syndrome. J Clin Invest 88:1976-1981

30. Grimminger F, Becker G, Seeger W (1988) High yield enzymatic conversion of intravascular leukotriene $\mathrm{A}_{4}$ in blood-free perfused lungs. J Immunol 141:2431-2436

31. Grimminger F, Menger M, Becker G, Seeger W (1988) Potentiation of leukotriene generation following sequestration of neutrophils in isolated lungs. Blood 72:1687-1692

32. Grimminger F, Kreusler B, Schneider U, Becker G, Seeger W (1990) Influence of microvascular adherence on neutrophil leukotriene generation - evidence for cooperative eicosanoid synthesis. J Immunol 144:1866-1872

33. Grimminger F, Kreusler B, Schneider U, von Witzleben E, Walmrath D, Neppert J, Seeger W (1991) Human leukoagglutinating antibody evokes cooperative leukotriene synthesis in pulmonary microvasculature - model of transfusion-related acute lung injury (TRALI). Circ Res 68: 503-512

34. Grimminger F, Sibelius U, Seeger W (1991) Amplification of $\mathrm{LTB}_{4}$ generation in AM-PMN cocultures: transcellular 5-lipoxygenase metabolism. Am J Physiol 261 : L195-L203

35. Grimminger F, von Kürten I, Walmrath D, Seeger W (1992) Type II alveolar epithelial eicosanoid metabolism - predominance of cyclooxygenase pathways, and transcellular lipoxygenase metabolism in co-culture with neutrophils. Am J Respir Cell Mol Biol 6:9-16

36. Gross TJ, Simon RH, Sitrin RG (1992) Tissue factor procoagulant expression by rat alveolar epithelial cells. Am J Respir Cell Mol Biol 6:397-403

37. Hall SB, Venkitaraman AR, Whitsett JA, Holm BA, Notter RH (1992) Importance of hydrophobic apoproteins as constituents of clinical exogenous surfactants. Am Rev Respir Dis $145: 24-30$

38. Hallman $M$ (1991) Lung surfactant in respiratory distress syndrome. Acta Anaesthesiol Scand 35 [Suppl 95]:1521

39. Hallman M, Spragg R, Harrell JH, Moser KM, Gluck $L$ (1982) Evidence of lung surfactant abnormality in respiratory failure. J Clin Invest 70:673-683

40. Hallman M, Maasilta P, Kivisaari L, Mattson K (1990) Changes in surfactant in bronchoalveolar lavage fluid after hemithorax irradiation in patients with mesothelioma. Am Rev Respir Dis 141:998-1005

41. Hamm H, Fabel H, Bartsch W (1992) The surfactant system of the adult lung: physiology and clinical perspectives. Clin Investig 70:637-657

42. Harwood JL (1987) Lung surfactant. Prog Lipid Res $26: 211-256$
43. Hasday JD, Bachwich PR, Lynch JP, Sitrin RG (1988) Procoagulant and plasminogen activator activities of bronchoalveolar fluid in patients with pulmonary sarcoidosis. Exp Lung Res 14:261-278

44. Hasleton PS (1983) Adult respiratory distress syndrome: a review. Histopathology 7:037-332

45. Hasleton PS (1983) The lung parenchyma in burns. Histopathology $7: 333-347$

46. Hawgood S (1989) Pulmonary surfactant apoproteins: a review of protein and genomic structure. Am J Physiol 257: L13-L22

47. Hawgood S, Benson BJ, Schilling J, Damm D, Clements JA, White RT (1987) Nucleotide and amino acid sequences of pulmonary surfactant protein SP 18 and evidence for cooperation between SP 18 and SP 28-36 in surfactant lipid adsorption. Proc Natl Acad Sci USA 84:66-70

48. Hayakawa H, Myrvik QN, St. Clair RW (1989) Pulmonary surfactant inhibits priming of rabbit alveolar macrophages. Am Rev Respir Dis 140:1390-1397

49. Hennes HM, Lee MB, Rimm AA, Shapiro DL (1991) Surfactant replacement therapy in respiratory distress syndrome. Am J Dis Child 145:102-104

50. Holm BA, Notter RH (1987) Effects of hemoglobin and cell membrane lipids on pulmonary surfactant activity. $\mathrm{J}$ Appl Physiol 63:1434-1442

51. Holm BA, Notter RH, Finkelstein JN (1985) Surface property changes from interactions of albumin with natural lung surfactant and extracted lung lipids. Chem Phys Lipids $38: 287-298$

52. Holm BA, Venkitaraman AR, Enhorning G, Notter RH (1990) Biophysical inhibition of synthetic lung surfactants. Chem Phys Lipids 52:243-250

53. Holm BA, Keicher L, Liu M, Sokolowski J, Enhorning G (1991) Inhibition of pulmonary surfactant function by phospholipases. J Appl Physiol 71:317-321

54. Huang YC, Fawcett TA, Moon RE, Fracia PJ, Simonson SG, Sane AC, Piantadosi CA, Young SL (1992) Exogenous surfactant treatment improves $\mathrm{V}_{\mathrm{A}} / \mathrm{Q}$ abnormalities in hyperoxic lung injury. Am Rev Respir Dis 145: A609

55. Idell S, Gonzalez KK, Bradford H, MacArthur CK, Fein AM, Maunder RJ, Garcia JGN, Griffith DE, Weiland J, Martin TR, McLarty J, Fair DS, Walsh PN, Colman RW (1987) Procoagulant activity in bronchoalveolar lavage in the adult respiratory distress syndrome. Am Rev Respir Dis 136:1466-1474

56. Idell S, Gonzalez KK, MacArthur CK, Gillies C, Walsh PN, McLarty J, Thrall RS (1987) Bronchoalveolar lavage procoagulant activity in bleomycin induced lung injury in marmosets. Am Rev Respir Dis 136:124-133

57. Idell S, Peterson BT, Gonzalez KK, Gray LD, Bach R, McLarty J, Fair DS (1988) Local abnormalities of coagulation and fibrinolysis and alveolar fibrin deposition in sheep with oleic acid-induced lung injury. Am Rev Respir Dis $138: 1282-1294$

58. Idell S, James KK, Gillies C, Fair DS, Thrall RS (1989) Abnormalities of pathways of fibrin turnover in lung lavage of rats with oleic acid and bleomycin-induced lung injury support alveolar fibrin deposition. Am J Pathol $135: 387-399$

59. Idell S, James KK, Levin EG, Schwartz BS, Manchanda N, Maunder RJ, Martin TR, McLarty J, Fair DS (1989) Local abnormalities in coagulation and fibrinolytic pathways predispose to alveolar fibrin deposition in the adult respiratory distress syndrome. J Clin Invest 84:695-705

60. Idell S, Peters J, James KK, Fair DS, Coalson JJ (1989) Local abnormalities of coagulation and fibrinolytic pathways that promote alveolar fibrin deposition in the lungs 
of baboons with diffuse alveolar damage. J Clin Invest 84:181-193

61. Idell S, Koenig KB, Fair DS, Martin TR, McLarty J, Maunder RJ (1991) Serial abnormalities of fibrin turnover in evolving adult respiratory distress syndrome. Am $\mathbf{J}$ Physiol 261: L240-L248

62. Ikegami M, Agata Y, Elkady T, Hallman M, Berry D, Jobe A (1987) Comparison of four surfactants: in vitro surface properties and responses of preterm lambs to treatment at birth. Pediatrics 79:39-46

63. Ikegami M, Jobe AH, Tabor BL, Rider ED, Lewis JF (1992) Lung albumin recovery in surfactant-treated preterm ventilated lambs. Am Rev Respir Dis 145:10051008

64. Iwaarden JF van, Welmers B, Verhoef J, Haagsman HP, Golde LMG van (1990) Pulmonary surfactant protein A enhances the host-defense mechanism of rat alveolar macrophages. Am J Respir Cell Mol Biol 2:91-98

65. Iwaarden JF van Strijp JAG van, Erbskamp MJM, Welmers AC, Verhoef J, Golde LMG van (1991) Surfactant protein $\mathrm{A}$ is opsonin in phagocytosis of herpes simplex virus type 1 by rat alveolar macrophages. Am J Physiol 261:L204-L209

66. Iwaarden JF van, Shimizu H, Golde PHM van, Voelker DR, Golde LMG van (1992) Rat surfactant protein D enhances the production of oxygen radicals by rat alveolar macrophages. Biochem J 286:5-8

67. Jackson LK (1982) Idiopathic pulmonary fibrosis. Clin Chest Med 3:579-592

68. Jefferies AL, Coates G, O'Brodovich H (1984) Pulmonary epithelial permeability in hyaline-membrane disease. $\mathrm{N}$ Engl J Med $311: 1075-1080$

69. Joka T, Obertacke U (1989) Neue medikamentöse Behandlung im ARDS: Effekt einer intrabronchialen xenogenen Surfactantapplikation. Z Herz- Thorax-Gefäßchirurgic 3 [Suppl 1]:21-24

70. Kaneko T, Sato T, Katsuya H, Miyauchi Y (1990) Surfactant therapy for pulmonary edema due to intratracheally injected bile acid. Crit Care Med 18:77-83

71. King RJ, MacBeth MC (1981) Interaction of the lipid and protein components of pulmonary surfactant. Role of phosphatidylglycerol and calcium. Biochim Biophys Acta 647:159-168

72. Kobayashi T, Ganzuka M, Taniguchi J, Nitta K, Murakami S (1990) Lung lavage and surfactant replacement for hydrochloric acid aspiration in rabbits. Acta Anaesthesiol Scand 34:216-221

73. Kobayashi T, Nitta K, Ganzuka M, Inui S, Grossmann $\mathrm{G}$, Robertson B (1991) Inactivation of exogenous surfactant by pulmonary edema fluid. Pediatr Res 29:353-356

74. Kuroki Y, Mason R, Voelker D (1988) Pulmonary surfactant apoprotein A structure and modulation of surfactant secretion by rat alveolar type II cells. J Biol Chem $263: 3388-3394$

75. Lamm WJE, Albert RK (1990) Surfactant replacement improves lung recoil in rabbit lungs after acid aspiration. Am Rev Respir Dis 142:1279-1283

76. Lee CT, Fein AM, Lippmann M, Holtzman H, Kimbel $P$, Weinbaum $G$ (1981) Elastolytic activity in pulmonary lavage fluid from patients with adult respiratory distress syndrome. N Engl J Med 304:192-196

77. Lewis JF, Ikegami M, Higuchi R, Jobe A, Absolom D (1991) Nebulized vs. instilled exogenous surfactant in an adult injury model. J Appl Physiol $71: 1270-1276$

78. Lewis JF, Ikegami M, Jobe AH (1992) Metabolism of exogenously administered surfactant in the acutely injured lungs of adult rabbits. Am Rev Respir Dis 145:19-23
79. Nakstadt B, Boye NP, Lyberg T (1987) Procoagulant activities in human alveolar macrophages. Eur J Respir Dis $71: 459-471$

80. Nakstad B, Lydberg T, Skjonsberg OH, Boye NP (1990) Local activation of the coagulation and fibrinolysis systems in lung disease. Thromb Res 57:827-838

81. Nieman GF, Bredenberg CE (1985) High surface tension pulmonary edema induced by detergent aerosol. J Appl Physiol 58:129-136

82. Nieman GF, Goyette D, Paskanik A, Brendenberg C (1990) Surfactant displacement by plasma lavage results in pulmonary edema. Surgery 107:677-683

83. Notter RH, Shaprio DL, Ohning B, Whitsett JA (1987) Biophysical activity of synthetic phospholipids combined with purified lung surfactant 6000 dalton apoprotein. Chem Phys Lipids 44:1-17

84. O'Brodovich HM, Weitz JI, Possmayer F (1990) Effect of fibrinogen degradation products and lung ground substance on surface function. Biol Neonate 57:325-333

85. Persson A, Chang D, Rust K, Moxley M, Longmore W, Crouch E (1989) Purification and biochemical characterization of CP4 (SP-D), a collagenous surfactant-associated protein. Biochemistry 28:6361-6367

86. Petty TL, Silvers GW, Paul GW, Stanford RE (1979) Abnormalities in lung elastic properties and surfactant function in adult respiratory distress syndrome. Chest 75:571574

87. Pison U, Seeger W, Buchhorn R, Joka T, Brand M, Obertacke U, Neuhof H, Schmit-Neuerburg KP (1989) Surfactant abnormalities in patients with respiratory failure after multiple trauma. Am Rev Respir Dis 140:1033-1039

88. Pison U, Tam EK, Caughey GH, Hawgood S (1989) Proteolytic inactivation of dog lung surfactant-associated proteins by neutrophil elastase. Biochim Biophys Acta 992:251-257

89. Pison U, Obertacke U, Seeger W, Hawgood S (1992) Surfactant protein A (SP-A) is decreased in acute parenchymal lung injury associated with polytrauma. Eur J Clin Invest

90. Possmayer F (1988) A proposed nomenclature for pulmonary surfactant-associated proteins. Am Rev Respir Dis 138:990-996

91. Pratt P (1977) The lung: structure, function, and disease. Williams and Wilkins, Baltimore, pp 45-57

92. Revak SD, Merritt TA, Hallman M, Cochrane CG (1986) Reconstitution of surfactant activity using purified human apoprotein and phospholipid measured in vitro and in vivo. Am Rev Respir Dis 134:1258-1265

93. Revak SD, Merritt TA, Degryse E, Stefani L, Courtney M, Hallman M, Cochrane CG (1988) Use of human surfactant low molecular apoproteins in the reconstitution of surfactant biologic activity. J Clin Invest 81:826-833

94. Reynolds HY (1989) Pulmonary host defenses - state of the art. Chest $95: 223 \mathrm{~S}-230 \mathrm{~S}$

95. Rice WR, Ross GF, Singleton FM, Dingle S, Whitsett JA (1987) Surfactant-associated protein inhibits phospholipid secretion from type II cells. J Appl Physiol 63:692698

96. Richman PS, Spragg RG, Robertson B, Merritt TA, Curstedt $\mathrm{T}$ (1989) The adult respiratory distress syndrome: first trials with surfactant replacement. Eur Respir J 2 [Suppl 3] :109 111

97. Robertson B, Lachmann B (1988) Experimental evaluation of surfactants for replacement therapy. Exp Lung Res 14:279-310

98. Ross GF, Notter RH, Meuth J, Whitsett JA (1986) Phospholipid binding and biophysical activity of pulmonary surfactant-associated protein (SAP)-35 and its non-collag- 
enous COOH-terminal domains. J Biol Chem 261:1428314291

99. Rüfer R, Stolz C (1969) Inaktivierung von alveolären Oberflächenfilmen durch Erniedrigung der Oberflächenspannung der Hypophase. Pflügers Arch 307:89-103

100. Ryan RM, Morris RE, Rice WR, Ciraolo G, Whitsett $\mathrm{J}$ (1989) Binding and uptake of pulmonary surfactant protein (SP-A) by pulmonary type II epithelial cells. J Histochem Cytochem 37:429-440

101. Ryan SF, Ghassibi Y, Liau DF (1990) Effects of activated polymorphonuclear leukocytes upon pulmonary surfactant in vitro. Am J Respir Cell Mol Biol 4:33-41

102. Seeger W, Lasch HG (1987) Septic lung. Rev Infect Dis $9: 570-579$

103. Seeger W, Suttorp N (1988) Role of membrane lipids in the pulmonary vascular abnormalities caused by bacterial toxins. Am Rev Respir Dis 136:462-466

104. Seeger W, Lepper H, Wolf HRD, Neuhof H (1985) Alteration of surfactant function after exposure to oxidative stress and to oxygenated and native arachidonic acid in vitro. Biochim Biophys Acta 835:58-67

105. Seeger W, Stöhr G, Wolf HRD, Neuhof H (1985) Alteration of surfactant function due to protein leakage: special interaction with fibrin monomer. J Appl Physiol 58:326-338

106. Seeger W, Walmrath D, Menger M, Neuhof H (1986) Increased lung vascular permeability after arachidonic acid and hydrostatic challenge. J Appl Physiol 61:1781-1789

107. Seeger W, Hübel J, Klapettek K, Pison U, Obertacke U, Joka T, Roka L (1991) Procoagulant activity in bronchoalveolar lavage of severly traumatized patients - relation to the development of acute respiratory distress. Throm Res 61:53-64

108. Seeger W, Thede C, Günther A, Grube C (1991) Surface properties and sensitivity to protein-inhibition of a recombinant apoprotein $\mathrm{C}$-based phospholipid mixture in vitro - comparison to natural surfactant. Biochim Biophys Acta 1081:45-52

109. Seeger W, Günther A, Thede C (1992) Differential sensitivity to fibrinogen-inhibition of SP-C versus SP-B based surfactants. Am J Physiol 262:L285-L291

110. Shiffer K, Hawgood S, Düzgünes N, Goerke J (1988) Interactions of the low molecular weight group of surfactantassociated proteins (SP 5-18) with pulmonary surfactant lipids. Biochemistry 27:2689-2695

111. Speer CP, Götze B, Curstedt T, Robertson B (1991) Phagocytic functions and tumor necrosis factor secretion of human monocytes exposed to natural porcine surfactant (Curosurf). Pediatr Res 30:69-74

112. Spencer H (1977) In: Pathology of the lung, 3rd edn. Saunders, Philadelphia, pp 235-240

113. Strohmaier W, Red1 H, Schlag G (1990) Studies of the potential role of a semisynthetic surfactant preparation in an experimental aspiration trauma in rabbits. Exp Lung Res 16:101-110

114. Suzuki Y, Fujita Y, Kogishi K (1989) Reconstitution of tubular myelin from synthetic lipids and proteins associated with pig pulmonary surfactant. Am Rev Respir Dis $140: 75-81$

115. Taylor FB, Abrams ME (1966) Effect of surface active lipoprotein on clotting and fibrinolysis, and of fibrinogen on surface tension of surface active lipoprotein. Am J Med $40: 346-350$

116. Tenner AJ, Robinson SL, Borchelt J, Wright JR (1989) Human pulmonary surfactant protein (SP-A), a protein structurally homologous to $\mathrm{C1q}$, can enhance $\mathrm{FcR}$ - and CR1-mediated phagocytosis. J Biol Chem 264:1392313928
117. Tierney DF, Johnson RP (1965) Altered surface tension of lung extracts and lung mechanics. $J$ Appl Physiol 20:1253-1260

118. van Daal GJ, So KL, Gommers D, Eijking EP, Fièvez RB, Sprenger MJ, van Dam DW, Lachman B (1991) Intratracheal surfactant administration restores gas exchange in experimental adult respiratory distress syndrome associated with viral pneumonia. Anesth Analg 72:589--595

119. van Daal GJ, Bos JAH, Eijking EP, Gommers D, Hannappel E, Lachmann B (1992) Surfactant replacement therapy improves pulmonary mechanics in end-stage influenza A pneumonia in mice. Am Rev Respir Dis 145:859-863

120. van Golde LMG, Batenburg JJ, Robertson B (1988) The pulmonary surfactant system: biochemical aspects and functional significance. Physiol Rev $68: 374-455$

121. Venkitaraman AR, Baatz JE, Whitsett JA, Hall SB, Notter RH (1991) Biophysical inhibition of synthetic phospholipid-lung surfactant apoprotein admixtures by plasma proteins. Chem Phys Lipids 57:49-57

122. Warr RG, Hawgood S, Buckley DI, Crisp TM, Schilling J, Benson BJ, Ballard PL, Clements JA, White RT (1987) Low molecular weight human pulmonary surfactant protein (SP5): isolation, characterization, and cDNA and amino acid sequences. Proc Natl Acad Sci USA 84:7915-7919

123. Whitsett JA, Ohning BL, Ross G, Meuth J, Weaver T, Holm BA, Shapiro DL, Notter RH (1986) Hydrophobic surfactant-associated protein in whole lung surfactant and its importance for biophysical activity in lung surfactant extracts used for replacement therapy. Pediatr Res 20:460467

124. Wichert P von, Temmesfeld M, Meyer W (1981) Influence of septic shock upon phosphytidylcholine remodeling mechanism in rat lung. Biochim Biophys Acta 664:487497

125. Williams MC, Hawgood S, Hamilton RL (1991) Changes in lipid structure produced by surfactant proteins SP-A, SP-B and SP-C. Am J Respir Cell Mol Biol 5:41-50

126. Wispé JR, Clark JC, Warner BB, Fajardo D, Hull WE, Holtzman RB, Whitsett JA (1990) Tumor necrosis factoralpha inhibits expression of pulmonary surfactant protein. J Clin Invest 86:1954-1960

127. Yu SH, Possmayer F (1986) Reconstitution of surfactant activity by using the $6 \mathrm{kDa}$ apoprotein associated with pulmonary surfactant. Biochem J 236:85-89

128. Yu SH, Possmayer F (1988) Comparative studies on the biophysical activities of the low-molecular-weight hydrophobic proteins purified from bovine pulmonary surfactant. Biochim Biophys Acta 961:337-350

129. Zelter M, Escudies BJ, Hoeffel JM, Murray JF (1990) Effects of aerosolized artificial surfactant on repeated oleic acid injury in sheep. Am Rev Respir Dis 141:1014-1019

130. Günther A, Bleyl H, Seeger W (1992) Apoprotein-based synthetic surfactants inhibit plasmic cleavage of fibrinogen in vitro. (submitted)

131. Seeger W, Elssner A, Günther A, Krämer HJ, Kalinowski HO (1992) Lung surfactant phospholipids associate with polymerizing fibrin - loss of surface activity. (submitted)

Received: October 20, 1992

Returned for revision: November 11, 1992

Accepted: November 20, 1992

Prof. Dr. W. Seeger

Medizinische Klinik

Klinikstrasse 36

W-6300 Gießen, Germany 